\title{
Doxorubicin and paclitaxel enhance the antitumor efficacy of vaccines directed against HER 2/neu in a murine mammary carcinoma model
}

\author{
Yesim Eralp ${ }^{1 *}$, Xiaoyan Wang ${ }^{1,2}$, Jian-Ping Wang ${ }^{1}$, Maureen F Maughan ${ }^{3}$, John M Polo 4 \\ and Lawrence B Lachman ${ }^{1,2}$ \\ 1Department of Bioimmunotherapy, The University of Texas MD Anderson Cancer Center, Houston, Texas, USA \\ ${ }^{2}$ The Graduate School of Biomedical Sciences, The University of Texas Health Sciences Center, Houston, Texas, USA \\ ${ }^{3}$ AlphaVax, Inc., Research Triangle Park, North Carolina, USA \\ ${ }^{4}$ Chiron Corporation, Emeryville, California, USA \\ ${ }^{*}$ Current address: University of Istanbul, Institute of Oncology, Istanbul, Turkey
}

Corresponding author: Lawrence B Lachman (e-mail: Lachman@odin.mdacc.tmc.edu)

Received: 13 Jan 2004 Revisions requested: 26 Feb 2004 Revisions received: 26 Feb 2004 Accepted: 11 Mar 2004 Published: 7 Apr 2004

Breast Cancer Res 2004, 6:R275-R283 (DOI 10.1186/bcr787)

(C) 2004 Eralp et al., licensee BioMed Central Ltd. This is an Open Access article: verbatim copying and redistribution of this article are permitted in all media for any purpose, provided this notice is preserved along with the article's original URL.

\begin{abstract}
Introduction: The purpose of the present study was to determine whether cytotoxic chemotherapeutic agents administered prior to immunotherapy with gene vaccines could augment the efficacy of the vaccines.

Methods: Mice were injected in the mammary fat pad with an aggressive breast tumor cell line that expresses HER2/neu. The mice were treated 3 days later with a noncurative dose of either doxorubicin or paclitaxel, and the following day with a gene vaccine to HER2/neu. Two more doses of vaccine were given 14 days apart. Two types of gene vaccines were tested: a plasmid vaccine encoding a self-replicating RNA (replicon) of Sindbis virus (SINCP), in which the viral structural proteins were replaced by the gene for neu; and a viral replicon particle derived from an attenuated strain of Venezuelan equine encephalitis virus, containing a replicon RNA in which the Venezuelan equine encephalitis virus structural proteins were replaced by the gene for neu.
\end{abstract}

\begin{abstract}
Results: Neither vaccination alone nor chemotherapy alone significantly reduced the growth of the mammary carcinoma. In contrast, chemotherapy followed by vaccination reduced tumor growth by a small, but significant amount. Antigen-specific $\mathrm{CD}^{+} \mathrm{T}$ lymphocytes were induced by the combined treatment, indicating that the control of tumor growth was most probably due to an immunological mechanism. The results demonstrated that doxorubicin and paclitaxel, commonly used chemotherapeutic agents for the treatment of breast cancer, when used at immunomodulating doses augmented the antitumor efficacy of gene vaccines directed against HER2/neu.
\end{abstract}

Conclusions: The combination of chemotherapeutic agents plus vaccine immunotherapy may induce a tumor-specific immune response that could be beneficial for the adjuvant treatment of patients with minimal residual disease. The regimen warrants further evaluation in a clinical setting.

Keywords: adjuvant treatment, breast cancer, chemotherapy, gene vaccines, immunotherapy

\section{Introduction}

Cancer treatment options directed at specific molecular targets, such as HER2/neu in breast cancer and c-kit in chronic myeloid leukemia and gastrointestinal stromal sarcomas, have proven effective [1-4]. HER2/neu is amplified in about $20-30 \%$ of human breast cancers and is a valuable biologic marker [5]. There is substantial evidence that overexpression of HER2/neu is associated with multiple adverse prognostic factors and aggressive clinical behavior, including early metastatic disease and unresponsiveness to current treatment modalities [6-8]. Immunotherapy could offer potential therapeutic benefit to patients with HER2/neu ${ }^{+}$tumors by impairing the downstream molecular signaling pathways, leading to

$\mathrm{CTL}=$ cytotoxic $\mathrm{T}$ lymphocytes; $\mathrm{DOX}=$ doxorubicin; FITC = fluorescein isothiocyanate; $\mathrm{HA}=$ hemagglutinin; IFN = interferon; IL = interleukin; PTX = paclitaxel; $T h=T$ helper $(T h)$ cells; VRP $=$ Venezuelan equine encephalitis virus replicon particles. 
tumor proliferation and resistance to established cytotoxic agents [9]. In breast cancer patients, traztuzumab has produced remarkable results, providing substantial support for an immunotherapeutic approach to cancer [10].

Vaccination as a form of specific immunotherapy for cancer has been considered for many years [11,12]. Tumors that express specific antigens, such as melanoma and breast cancer, are considered suitable candidates for vaccine therapy $[13,14]$. Peptide antigens resulting from amplified gene transcription and translation are expressed on the cell surface in the context of class I histocompatibility antigens and constitute a well-defined target for cytotoxic T-cell-mediated destruction [15,16]. Encouraging in vitro and animal studies have led to several clinical trials of vaccine therapy for malignant disorders $[13,17,18]$. Although a few phase I trials and one phase III trial have indicated a possible benefit from vaccine therapy in an adjuvant setting, vaccination remains an experimental modality of cancer treatment [19].

The HER2/neu gene encodes a $185 \mathrm{kDa}$ transmembrane growth factor receptor ( 185 ) with tyrosine kinase activity [20]. Although normally expressed in many cells throughout the body, p185 is greatly overexpressed on the plasma membrane of some tumor cells. This overexpression makes the tumor cells recognizable by the immune system [21]. Tumors can circumvent the immune response, however, by downregulating an overexpressed antigen such as p185 or by secreting immune response blocking cytokines such as transforming growth factor beta [19]. Also, since tumor cells are derived from normal cells, host tolerance often extends to the tumor [22].

As demonstrated by several groups [23-27], including our own [28], DNA or gene vaccines directed against HER2/neu protected mice from challenge with HER2/neuoverexpressing murine mammary tumor cell lines. In addition, treatment with a gene vaccine prolonged the survival of neu transgenic mice, although all the mice eventually developed fatal breast tumors [28]. Thus, although vaccination prior to challenge with a breast tumor can prevent tumor growth, stopping the growth of an existing tumor remains to be accomplished in murine models.

In the search for alternatives that could increase the efficacy of vaccine treatment, we focused our efforts on adjunctive chemotherapy. Previous publications note that chemotherapeutic agents administered at low doses increased immune-mediated tumor destruction through stimulation of cytotoxic lymphocytes and induction of mediators that are directly or indirectly involved in cell killing [29-32]. Other publications have contained preclinical and clinical data demonstrating increased tumor control with treatment modalities that combine these reports, we tested whether vaccine therapy combined with cytotoxic chemotherapeutic agents could augment the efficacy of either agent used alone in a rapidly growing murine mammary tumor model.

\section{Materials and methods Cell lines}

The previously described A2L2 cells were maintained in monolayer culture in Eagle's minimum essential medium supplemented with $5 \%$ fetal calf serum, sodium pyruvate, nonessential amino acids, L-glutamine, and vitamins (GIBCO-BRL, Grand Island, NY, USA), incubated in a humidified $5 \% \mathrm{CO}_{2}-95 \%$ air incubator at $37^{\circ} \mathrm{C}$ [28].

\section{Mice}

Female BALB/c mice (6-8 weeks of age, weighing approximately $20 \mathrm{~g}$ ) were purchased from the National Cancer Institute (Frederick, MD, USA). All experiments were performed in accordance with pre-approved institutional protocols and with the guidelines of the Animal Care and Use Committee of the University of Texas MD Anderson Cancer Center.

\section{Tumor injection and chemotherapeutic agents}

The cytotoxic effects of doxorubicin (DOX) and paclitaxel (PTX) on A2L2 cells were determined by in vitro growth inhibition assays. For in vitro tests, DOX and PTX were purchased in crystalline form (Sigma Chemicals, St Louis, $\mathrm{MO}, \mathrm{USA})$. One-use aliquots of PTX $(0.01 \mathrm{M}$ in dimethylsulfoxide) were stored at $-20^{\circ} \mathrm{C}$, and one-use aliquots of DOX $\left(2 \mathrm{mg} / \mathrm{ml}\right.$ in sterile normal saline) were stored at $4^{\circ} \mathrm{C}$.

For in vivo experiments, DOX (Gencia, Irvine, CA, USA) and PTX $\left(\right.$ Taxol $^{\circledR}$; Bristol-Myers Squibb, Princeton, NJ, USA) were diluted in $0.9 \%$ sterile sodium chloride solution before injection. To determine the in vivo efficacy and the optimal dose of each agent that would result in an approximately $50 \%$ reduction in tumor growth, preparatory dose-finding experiments were performed. Both chemotherapeutic drugs were administered 3 days after a tumor challenge of $2.5 \times 10^{4}$ A2L2 cells injected into the mammary fat pad.

Mice were anesthetized by inhalation of isoflurane using a special apparatus developed by the veterinarians at the University of Texas MD Anderson Cancer Center. A $0.5 \mathrm{~cm}$ incision was made above the top-most breast to reveal the underlying fat pad. A suspension of $2.5 \times 10^{4}$ A2L2 cells were injected in $0.1 \mathrm{ml}$ normal saline. The incision was closed with a wound clip. These wound clips were removed after 7 days (if they had not fallen off already). Tumor dimensions were measured in perpendicular directions three times a week with microcalipers, and the tumor mass was calculated using the following formula: tumor mass $=\left(a \times b^{2}\right) / 2$, where $a$ is the largest diameter and $b$ is the shortest dimension perpendicular to $a$. 
DOX was given intravenously via the tail vein at doses ranging from 2.5 to $10.0 \mathrm{mg} / \mathrm{kg}$, and PTX was given intraperitoneally at dose levels ranging from 10.0 to $30.0 \mathrm{mg} / \mathrm{kg}$. The dose causing a $50 \%$ reduction in tumor growth was determined as $5.0 \mathrm{mg} / \mathrm{kg}$ for DOX and as $25.0 \mathrm{mg} / \mathrm{kg}$ for PTX based upon effectiveness.

To eliminate the possibility that the A2L2 cell line was resistant to DOX and PTX, we performed an in vitro viability assay. Both DOX and PTX killed A2L2 cells in a dose-dependent manner (data not shown).

\section{Plasmid vaccine}

The SINCP- $\beta$ gal plasmid was obtained from Chiron Corp. (Emeryville, CA, USA) and has been described in detail elsewhere $[41,42]$. The vaccine is designed to generate a self-replicating vector RNA (replicon) based on Sindbis virus [42] and was prepared as follows. The rat neu sequence was excised from the plasmid pSV2neu (obtained from Dr M-C Hung, University of Texas MD Anderson Cancer Center) and was inserted into SINCP following excision of the gene for $\beta$-gal. This plasmid was designated SINCP-neu. Mice were vaccinated in the quadriceps muscle by injections containing $100 \mu \mathrm{g}$ SINCP-neu in $100 \mu \mathrm{l}$ of $0.25 \%$ bupivacaine (Sigma Chemicals) in normal saline using a 26-gauge needle.

\section{Venezuelan equine encephalitis virus replicon particles vaccine}

Venezuelan equine encephalitis virus replicon particles (VRP) encoding the same rat neu gene were prepared by AlphaVax (Research Triangle Park, NC, USA). VRP vaccines are virus replicon particles comprised of the Venezuelan equine encephalitis virus structural proteins containing a replicon RNA expressing heterologous genes. The preparation of VRP has been described in detail previously [43]. VRP-neu or a control vaccine encoding the hemagglutinin (HA) gene of the influenza virus, VRP-HA, were injected into the foot pad of mice in a volume of $10 \mu \mathrm{l}$ containing $10^{6}$ infectious units using a $25 \mu \mathrm{l} \mathrm{Hamilton}$ syringe with an attached 26-gauge needle (Hamilton Co., Reno, NV, USA).

\section{Experimental tumor model and treatment}

The 'race model' is an experimental design for investigating the efficacy of sequentially administered chemotherapy followed by the vaccine in a large tumor burden setting. In this model, cytotoxic drugs are administered on the third day following tumor cell injection and the vaccine is administered 1 day later. All immunizations were started on the fourth day after tumor cell injection and were repeated on days 18 and 32. A different foot was injected each time. Appropriate controls, including normal saline for DOX and 10\% cremaphor/10\% ethanol (Sigma Chemicals) for PTX, were included in all experiments. Mice with tumors weighing $1 \mathrm{~g}$ received euthanasia in a $\mathrm{CO}_{2}$ chamber.

\section{In vitro growth inhibition assay}

A2L2 cells were suspended in culture medium at a density of $3 \times 10^{4} \mathrm{cells} / \mathrm{ml}$. Then $1.5 \times 10^{3}$ cells in $50 \mu \mathrm{l}$ were plated into 96-well flat-bottom plates. Following incubation for 24 hours at $37^{\circ} \mathrm{C}$, drugs, vehicles and controls consisting only of medium and cells were dispensed in $50 \mu \mathrm{l}$ volumes in duplicate into the appropriate wells. DOX was tested at concentrations ranging from 0.0625 to $125 \mu \mathrm{g} / \mathrm{ml}$, and PTX was tested at concentrations ranging from 0.1875 to $375 \mu \mathrm{g} / \mathrm{ml}$.

Cell viability was assessed by the MTS-CellTiter $96^{\circledR}$ aqueous non-radioactive cell proliferation assay (Promega, Madison, WI, USA) according to the manufacturer's protocol at 24 and 48 hours of culture. Because the tetrazolium compound of MTS-CellTiter $96^{\circledR}$ is bioreduced into a formazan, its metabolism could be assayed by optical density at $490 \mathrm{~nm}$ using a photometric plate reader.

\section{In vitro cell cultures}

Spleens from treated mice were removed aseptically and homogenized gently between two frosted slides. The splenocytes were cultured in RPMl 1640 supplemented with $10 \%$ fetal bovine serum (HyClone, Logan, UT, USA), $1 \%$ nonessential amino acids, $100 \mathrm{mM}$ sodium pyruvate, $2 \mathrm{mM}$ L-glutamine, $100 \mathrm{U} / \mathrm{ml}$ penicillin, $100 \mu \mathrm{g} / \mathrm{ml}$ streptomycin, and $50 \mu \mathrm{M}$ 2-mercaptoethanol (GIBCO-BRL). Splenocyte cultures were incubated with a specific peptide (described next) for 5 days in a humidified $5 \%$ $\mathrm{CO}_{2}-95 \%$ air incubator at $37^{\circ} \mathrm{C}$ before cytokine analysis.

\section{Synthetic peptide}

The rat HER2/neu-derived peptide HER2p780 (amino acids 780-788; PYVSRLLGI) was obtained from $M$ Campbell (Peptide Synthesis Facility, University of Texas MD Anderson Cancer Center). This peptide was previously shown to induce specific immunity against HER2/neu [44]. HER2p780 in crystalline form was dissolved in complete culture medium and mixed with the splenocyte cultures at a concentration of $70 \mu \mathrm{g} / \mathrm{ml}$.

\section{Measurement of intracellular IFN- $\gamma$ levels}

To enhance intracellular cytokine levels, peptidestimulated splenocytes were resuspended at a density of $(1-2) \times 10^{6} \mathrm{cells} / \mathrm{ml}$, and cells were reactivated by 6 -hour incubation at $37^{\circ} \mathrm{C}$ in the presence of $10 \mathrm{ng} / \mathrm{ml}$ phorbol 12-myristate 13-acetate (Sigma Chemicals), $250 \mathrm{ng} / \mathrm{ml}$ calcium ionophore (Sigma Chemicals) and $1 \mu \mathrm{l} / \mathrm{ml}$ brefeldin A (GolgiPlu ${ }^{\mathrm{TM}}$; BD Pharmingen Biosciences, San Diego, CA, USA). The cells were then treated with Fc block (BD Pharmingen Biosciences) for $15 \mathrm{~min}$ to reduce nonspecific binding. 
Fixation, permeabilization, and staining with FITC-labeled anti-IFN- $\gamma$, with peridinin chlorophyll protein-conjugated anti-CD3 and with phycoerythrin-conjugated anti-CD8 monoclonal antibodies (BD Pharmingen Biosciences) were performed according to the manufacturer's protocol. A positive control using commercially obtained MIC-1 cells (BD Pharmingen Biosciences) and negative controls with nonstimulated splenocytes were also included.

To rule out nonspecific background staining, we used isotype controls (BD Pharmingen Biosciences) for each monoclonal antibody. Samples were analyzed by three-color flow cytometry analysis using a FACS Calibur (BD, Franklin Lakes, NJ, USA), and data were analyzed using WinMDI 2.8 software (freely downlaodable from http://facs.scripps.edu)).

\section{Statistical analysis}

All statistical analyses were performed by two-way analysis of variance using Prism 4.0 software (Graphpad Software, San Diego, CA, USA). The error bars in Figures 1-3 represent the standard error of the mean. Statistical analysis, power analysis and the sample size per group were evaluated and found to be statistically acceptable by Lyle Broemling, PhD, Associated Professor of Biostatistics, University of Texas MD Anderson Cancer Center.

\section{Results}

\section{The antitumor effect of DOX followed by vaccination} with SINCP-neu

Using the race model, we investigated the efficacy of chemotherapy followed by vaccination to inhibit tumor growth. The cytotoxic agent DOX was administered 3 days after inoculation of $2.5 \times 10^{4}$ A2L2 cells in the mammary fat pad. Either the SINCP-neu plasmid gene vaccine or the control plasmid SINCP- $\beta$ gal was administered 1 day later and administered again on days 18 and 32.

Tumor growth over a period of 42 days is shown in Fig. 1 . The group of 10 mice treated with DOX and SINCP-neu had a significant delay in tumor progression compared with the mice treated with DOX and SINCP- $\beta$ gal $(P<0.0001)$. The mean tumor mass for the SINCP- $\beta$ gal plasmid control group on day 40 was $1062.8 \pm 44.8 \mathrm{mg}$, compared with $888.5 \pm 51.7 \mathrm{mg}$ for the SINCP-neu group. Control groups of 10 mice receiving treatment with only DOX, SINCP- $\beta$ gal, SINCP-neu or normal saline had nearly identical tumor growth to that in the group given DOX followed by SINCP- $\beta$ gal; the mean tumor mass for these four control groups was greater than $1 \mathrm{~g}$ by day 42 . The day 42 mean value for DOX alone (open square) and the day 36 mean value for normal saline (inverted triangle) are shown in Fig. 1. The only significant difference in any of the control groups was for the mice treated with only normal saline; these mice were sacrificed on day 36
Figure 1

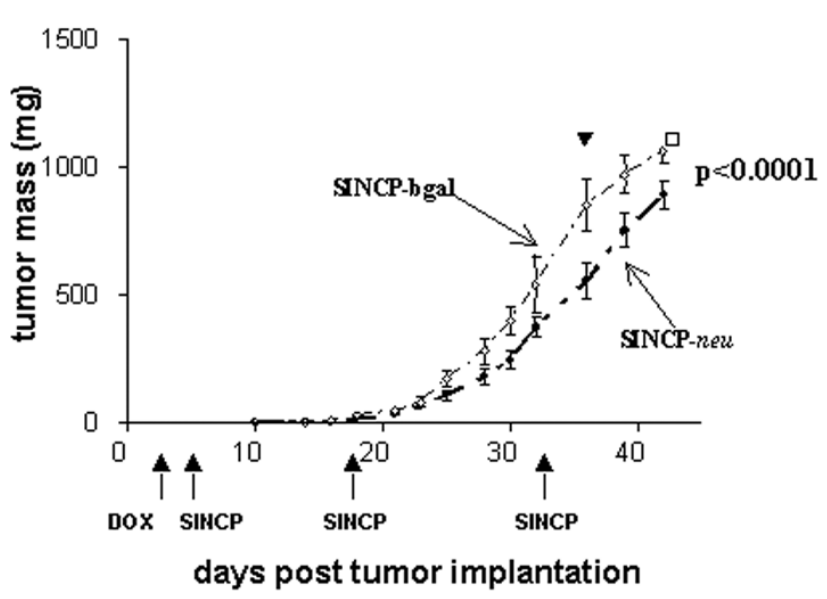

Tumor growth in groups of 10 mice treated with doxorubicin (DOX) followed by the plasmid gene vaccine SINCP-neu (lower line) containing the gene for neu, compared with DOX followed by the negative control plasmid vaccine SINCP- $\beta$ gal lacking the gene for neu (upper line). The mean tumor volume for mice treated with only DOX $(\square)$ is shown for day 42 , and the mean tumor volume for mice treated with only normal saline $(\boldsymbol{\nabla})$ is shown for day 36 .

\section{Absence of an antitumor effect of PTX followed by vaccination with SINCP-neu}

Again using the race model, we investigated the efficacy of PTX followed by vaccination to inhibit tumor growth. PTX was administered 3 days after inoculation of $2.5 \times 10^{4}$ A2L2 cells in the mammary fat pad, and either SINCP-neu or SINCP- $\beta$ gal was administered 1 day later and administered again on days 18 and 32. Tumor growth was monitored for a total of 35 days. Unlike the results for DOX (Fig. 1), PTX treatment followed by vaccination did not significantly reduce tumor growth. PTX alone did not reduce tumor growth compared with the vehicle of $10 \%$ cremaphor $10 \%$ ethanol used to dissolve the PTX, and there was no reduction in tumor growth by either SINCPneu or SINCP-ßgal used alone (data not shown).

\section{Antitumor effect of VRP-neu with DOX or PTX}

In our next experiment, we again used the race model to evaluate the combined effect of either DOX or PTX followed by vaccination. As shown in Fig. 2, tumor progression was significantly delayed in mice treated with DOX followed by VRP-neu compared with mice treated with DOX followed by VRP-HA $(P<0.0001)$. The mean tumor mass on day 35 for mice treated with DOX and VRP-neu was $416.3 \pm 47.6 \mathrm{mg}$, compared with $720.6 \pm 133.8 \mathrm{mg}$ for mice treated with DOX and VRP-HA. The mean for the DOX and VRP-neu group was also significantly less than that for mice treated with DOX alone (Fig. 2, open square) or with normal saline (Fig. 2, inverted triangle). 
Figure 2

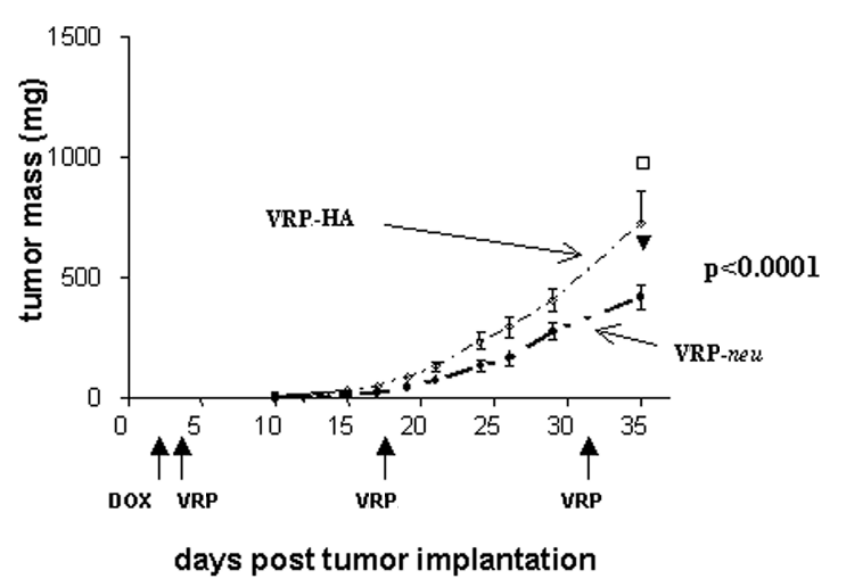

Tumor growth in 10 mice treated with doxorubicin (DOX) and the viral replicon gene vaccine Venezuelan equine encephalitis virus replicon particles (VRP)-neu containing the gene for neu (lower line), compared with eight mice treated with DOX and the negative control viral replicon gene vaccine VRP-hemagglutinin (HA) lacking the gene for neu (upper line). DOX alone $(\square)$ or saline alone $(\boldsymbol{\nabla})$ were also tested in groups of eight and 10 mice, respectively, and the values are shown for day 35 .

When PTX was substituted for DOX in the race model, tumor growth was again significantly delayed for vaccination with VRP-neu compared with vaccination with VRP-HA (Fig. 3). In this experiment the mean tumor mass on day 35 for mice treated with PTX and VRP-neu was $525.4 \pm 44.4 \mathrm{mg}$, compared with $723.6 \pm 108.5 \mathrm{mg}$ for mice treated with PTX and VRP-HA. The mean tumor mass for the PTX and VRP-neu group on day 35 was also significantly lower than for groups of control mice treated with only PTX (Fig. 3, open square) or with only the vehicle control (Fig. 3, inverted triangle).

Induction of antigen-specific CD8 ${ }^{+} /$IFN $-\gamma^{+} \mathrm{T}$ lymphocytes Cytotoxic T lymphocytes (CTL) form a distinct CD8 ${ }^{+} \mathrm{T}$-cell population that is capable of killing antigen-bearing target cells after interacting with the T-cell antigen receptor [45]. The generation of such protective immunity against foreign antigens is coordinated to a large extent by cytokines produced by certain T-cell subsets. IFN- $\gamma$ is a relevant mediator in the activation of CTL populations by Th cells [46]. Furthermore, in vitro studies have revealed substantial evidence supporting a direct correlation between IFN- $\gamma$ production and CTL activity $[25,47-52]$.

To determine the underlying mechanism of tumor growth inhibition by our treatment groups, we compared the number of HER2/neu-specific $\mathrm{CD}^{+}$cells containing intracellular IFN- $\gamma$ after various treatments. As shown in Fig. 4, PYVSRLLGI-stimulated spleen cells from mice treated with DOX and vaccinated with VRP-neu had $2.16 \%$ CD8 ${ }^{+}$IFN- $\gamma^{+}$cells, compared with $0.29 \%$ for mice treated
Figure 3

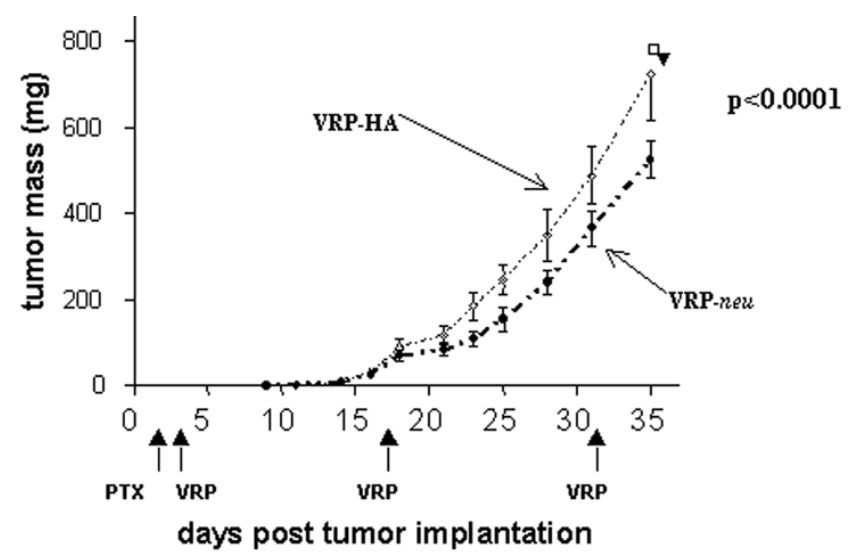

Tumor growth in groups of 10 mice treated with paclitaxel (PTX) and the viral replicon gene vaccine Venezuelan equine encephalitis virus replicon particles (VRP)-neu containing the gene for neu (lower line), compared with mice treated PTX and the negative control viral replicon gene vaccine VRP-hemagglutinin (HA) lacking the gene for neu (upper line). PTX alone $(\square)$ or vehicle control $(\boldsymbol{\nabla})$ were also tested in groups of 10 mice, and the values are shown for day 35.

with DOX and vaccinated with VRP-HA. Similarly, PYVSRLLGI-stimulated spleen cells from mice treated with PTX and vaccinated with VRP-neu had 2.25\% CD8 ${ }^{+}$IFN- $\gamma^{+}$cells, compared with $0.52 \%$ for mice treated with PTX and vaccinated with VRP-HA.

Treatment with chemotherapy followed by vaccination with VRP-neu clearly induced antigen-specific CD8 ${ }^{+} \mathrm{IFN}-\gamma^{+}$ $T$ lymphocytes. This same effect was not evident for mice vaccinated with SINCP-neu, implying that VPR-neu may be a much more powerful gene vaccine than SINCP-neu. As presented in Table 1, treatment with PTX increased the number of $\mathrm{CD}^{+} \mathrm{IFN}-\gamma^{+}$cells after PYVSRLLGI stimulation compared with untreated mice; however, this effect was not potentiated by vaccination with SINCP-neu compared with vaccination with SINCP- $\beta$ gal. Treatment with DOX did not increase the baseline number of $\mathrm{CD}^{+} \mathrm{IFN}-\gamma^{+}$after PYVSRLLGI stimulation as much as did treatment with PTX. Also, vaccination with SINCP-neu compared with vaccination with SINCP- $\beta$ gal was without effect.

\section{Discussion}

In the present study we demonstrate the synergistic enhancement of the antitumor effect of combined chemotherapy and vaccine immunotherapy on tumor-bearing mice. At the doses used, the chemotherapeutic agents DOX and PTX had a minimal effect on the growth of a preexisting breast tumor when used alone (data not shown). Similarly, the vaccines SINCP-neu and VRP-neu were not effective at controlling the growth of a pre-existing tumor (data not shown). These findings are in agreement with 
Figure 4

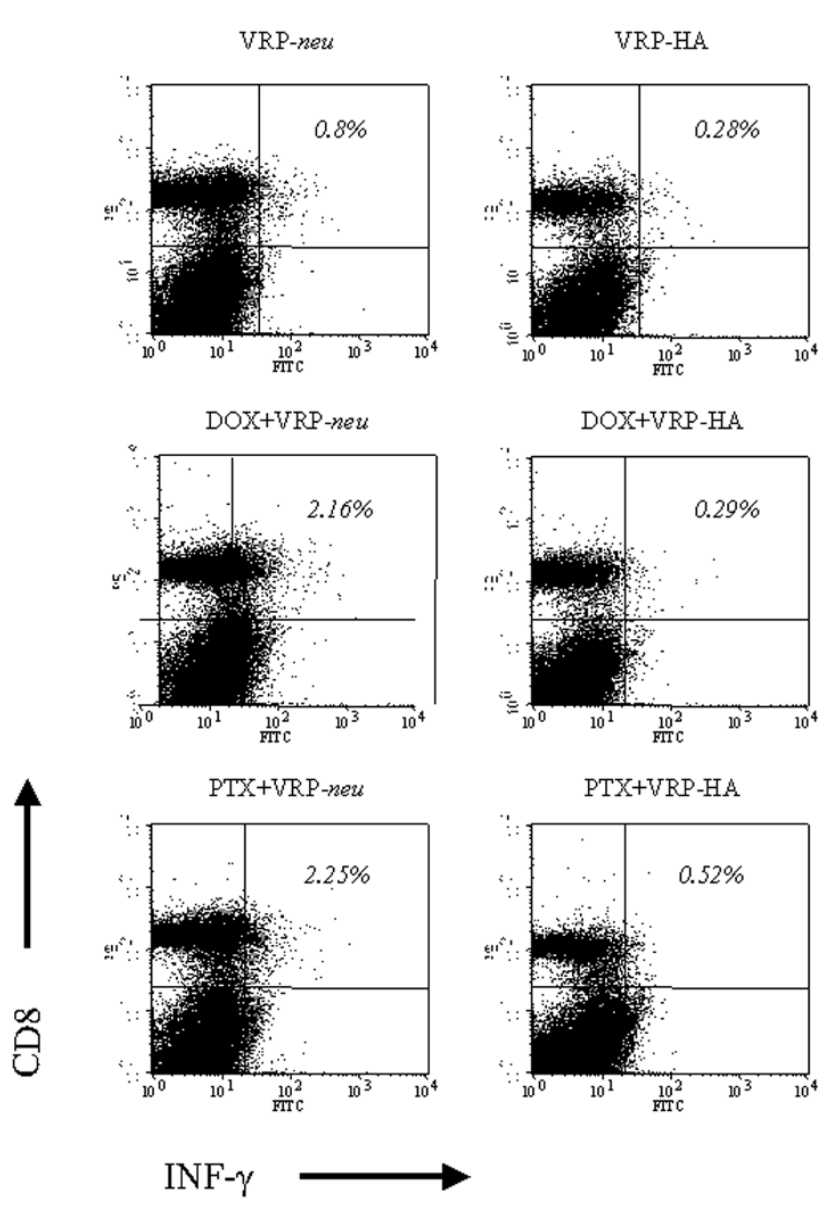

Flow cytometric analysis of $\mathrm{CD}^{+}$and intracellular IFN- $\gamma^{+}$lymphocytes following treatment of mice with doxorubicin (DOX) or with paclitaxel (PTX) and vaccination with the viral replicon gene vaccine Venezuelan equine encephalitis virus replicon particles (VRP)-neu containing the gene for neu or the negative control viral replicon gene vaccine VRPhemagglutinin (HA) lacking the gene for neu.

\section{Table 1}

Induction of cytotoxic T lymphocytes following vaccinationa

\begin{tabular}{llcc}
\hline & \multicolumn{3}{c}{ CD8+ IFN- $\gamma^{+}$cells/CD8+ cells (\%) } \\
\cline { 2 - 4 } Vaccination & None & Doxorubicin & Paclitaxel \\
\hline VRP-HA & 0.28 & 0.29 & 0.52 \\
VRP-neu & 0.80 & 2.16 & 2.25 \\
SINCP-Bgal & 0.45 & 0.56 & 1.44 \\
SINCP-neu & 0.39 & 0.37 & 1.08 \\
\hline
\end{tabular}

a Immune spleen cells from mice treated with either doxorubicin or paclitaxel and vaccinated with SINCP- $\beta g a l$, SINCP-neu, Venezuelan equine encephalitis virus replicon particles-hemagglutinin (VRP-HA) or Venezuelan equine encephalitis virus replicon particles-neu (VRP-neu) were cultured for 5 days with the peptide PYVSRLLGI. Dual-positive cells expressing CD8 and intracellular IFN- $\gamma$ were quantified by flow previous data showing that a number of current vaccines developed against tumor-associated antigens have failed to prevent growth and metastasis of established tumors in both animal and human studies, despite documentation of antigen-directed immune activation [12,45,53].

Various approaches to overcoming the low immunogenicity of vaccines or to optimize antigen presentation have yielded promising results, and many preclinical and clinical investigational studies are under way [22,54-57]. Nonetheless, the use of cancer vaccines is at present limited to adjuvant therapy, preferably in the setting of minimal residual disease.

We have previously shown that the plasmid ELVIS-neu, an earlier version of the plasmid SINCP-neu used in this project, induced antitumor immunity when used to vaccinate mice prior to tumor challenge [28]. Vaccination with ELVIS-neu also prolonged the survival of neu transgenic mice, although all the mice eventually died [28]. In a similar experiment using neu transgenic mice, vaccination with VRP-neu produced a much better result: $100 \%$ of the mice survived and none had breast tumors on postmortem examination (unpublished result). This result clearly demonstrated that VRP-neu was much more effective for this application than ELVIS-neu and, by inference, that VRP-neu is also better than the slightly modified SINCP-neu. However, as already described, both SINCP-neu and VRP-neu when used as single agents were ineffective in the race model. Based upon these findings, we studied whether combining chemotherapy and vaccine immunotherapy would be more effective in the race model than either agent used alone.

The two chemotherapeutic agents tested in this study, DOX and PTX, are both potent anticancer agents established as standard adjuvant therapy for breast cancer [58]. To eliminate the possibility that the A2L2 cell line was resistant to DOX and PTX $[59,60]$, we performed an in vitro viability assay. Both DOX and PTX killed A2L2 cells in a dose-dependent manner (data not shown). We next identified the dose of each agent that would reduce tumor growth by approximately 50\%. Many animal studies demonstrated the effectiveness of cyclophosphamide, melphalan and DOX administered at doses as low as $3-10 \%$ of the usual cytotoxic level $[30,61,62]$. The doses of DOX $(5 \mathrm{mg} / \mathrm{kg})$ and of PTX $(25 \mathrm{mg} / \mathrm{kg})$ used in our investigation are sufficiently low to maintain lymphocyte effector cell activity as demonstrated by the ability of the vaccines to induce antitumor immunity. It has been documented previously that some chemotherapeutic drugs administered at suboptimal doses may have an immunomodulatory activity [37,63].

We demonstrated in the present study that DOX administered at $5 \mathrm{mg} / \mathrm{kg}$ prior to vaccination enhanced the 
effectiveness of both the SINCP-neu gene vaccine (Fig. 1) and the VRP-neu gene vaccine (Fig. 2). PTX administered at $25 \mathrm{mg} / \mathrm{kg}$, on the other hand, increased the effectiveness of only the VRP-neu vaccine (Fig. 3). The in vivo antitumor efficacy of PTX followed by SINCP-neu was attributed exclusively to the effect of PTX and not to the effect of the vaccine. The analysis of cellular immune responses induced by combined chemotherapy and VRPneu vaccine therapy was in agreement with the in vivo data that both DOX and PTX induced a high level of antigen-specific CD8+IFN- $\gamma^{+}$cells (Fig. 4 and Table 1 ).

Although DOX and PTX induced neu-specific CD8 ${ }^{+}$T-cell activity when combined with VRP-neu, neither the vaccine alone nor the chemotherapy alone generated an antigenspecific immune response by itself. DOX has been shown to cause monocyte-macrophage functional differentiation, which induces an augmented phagocytic activity as well as an increased secretion of several cytokines such as IL-1, IL-2, or tumor necrosis factor [62]. The immune activity of DOX has therefore been linked to improved antigen targeting and shifting of the immune response from a Th2 type to a Th1 type, as well as an increase in antigen-stimulated CTL activity [30,64-66].

DOX, given 7 days after an autologous vaccine engineered to secrete granulocyte-macrophage colonystimulating factor, was also shown by Mihich and colleagues to enhance CD8 ${ }^{+}$CTL activity [66]. However, this result was not confirmed in a subsequent study by the same group [64]. Although Nigam and colleagues showed substantial CTL activity when DOX was given concomitantly with vaccine, they did not observe a response when chemotherapy was administered 1 week earlier than the vaccine, demonstrating the importance of the schedule of administration [67]. The present data revealed that DOX could induce an antigen-specific $\mathrm{CD} 8^{+}$ $\mathrm{T}$-cell response when given 1 day before the vaccine; however, if given 1 week after the vaccine, no $\mathrm{CD} 8^{+} \mathrm{T}$-cell response was observed (data not shown).

Based on previous findings and data with the VRP-neu vaccine described in the present article, it can be postulated that the immunomodulatory effect of DOX and PTX in priming immune cells to the antigen starts within 1 week after the administration of the drug, and it appears to enhance the capability of the vaccine to induce antigenspecific $\mathrm{CD}^{+}{ }^{+}$-cell activity, probably by increasing antigen presentation to effector cells through its augmentation of phagocytic activity. Supporting this hypothesis, Orsini and colleagues demonstrated that an increase in the number of monocytic cells occurs 5 days after DOX administration in the spleens of mice [68].

Although we have identified one mechanism underlying the immune-enhancing effect of cytotoxic agents, other mechanisms may be involved. This is clearly evident in our data demonstrating that DOX and SINCP-neu inhibited tumor growth in vivo (Fig. 1) but failed to induce antigenspecific CD8 ${ }^{+} \mathrm{T}$ cells (Table 1 ). An alternative mechanism is thus probably responsible for the antitumor effect of DOX administration followed by SINCP-neu, and may explain why PTX administration followed by SINCP-neu was totally ineffective in controlling tumor growth.

Similar to DOX, PTX has been shown to activate macrophages directly, thus augmenting the antitumor effector function and inducing the secretion of relevant cytokines such as tumor necrosis factor, IL-12, and granulocytemacrophage colony-stimulating factor [37]. When combined with SINCP-neu or with SINCP-ßgal, however, PTX increased the neu-specific $\mathrm{CD}^{+}{ }^{+} \mathrm{T}$-cell response by approximately twofold, implying that PTX is capable of inducing a tumor-specific immune response by itself rather than through a synergistic interaction.

Several studies have reported enhanced antitumor activity of low-dose to moderate-dose chemotherapy combined with autologous cell vaccines [33-35,37,38], some of which have been modified to improve the potency of the vaccine [37,67]. Recently, in a murine model of acute promyelocytic leukemia, the efficacy of a DNA vaccine to the oncogenic promyelocytic leukemia-retinoic acid receptor alpha was significantly increased when combined with the standard all-trans retinoic acid $[39,40]$. In the present study we found enhanced inhibition of tumor growth with VRP vaccine expressing neu combined with either DOX or PTX, possibly mediated through generation of an antigen-specific CTL response [48-52]. DOX also yielded an improved antitumor efficacy when combined with a DNA plasmid designed to generate a Sindbis virus replicon expressing neu.

Further studies are required to determine whether the combination of chemotherapy and vaccine therapy will prolong the survival of mice in a 'surgical model' in which the tumor is surgically removed prior to treatment.

\section{Conclusions}

The results of this study demonstrate that DOX and PTX have potential immunomodulatory activities that can be used to improve the antitumor efficacy of gene vaccines. The race model utilized in these studies is a very rigorous model employing a rapidly growing tumor. The VRP-neu vaccine, the more effective of the two vaccines evaluated, induced $\mathrm{CD}^{+} \mathrm{IFN}-\gamma^{+} \mathrm{T}$-cell responses, demonstrating a potential immunological mechanism for the observed delayed tumor growth. Additional studies are required to identify other possible biological mechanisms, as well as the optimal dosage and schedules of other potential combination regimens using cytotoxic agents and gene vaccines. 


\section{Authors' contributions}

The authors' contributions to this research are reflected in the order shown, with the exception of LBL who supervised all aspects of this research and the preparation of this report.

\section{Competing interests}

None declared.

\section{Acknowledgements}

This research was supported by the US Army Medical Research and Materiel Command, Department of Defense Breast Cancer Research Program, BC980071, by the WM Keck Center for Cancer Gene Therapy, and by the Cancer Center Core Grant CA16672. The authors thank Walter Pagel, Office of Scientific Publications for editing the manuscript.

\section{References}

1. Kim JA: Targeted therapies for the treatment of cancer. Am J Surg 2003, 186:264-268.

2. Nahta R, Hortobagyi GN, Esteva FJ: Growth factor receptors in breast cancer: potential for therapeutic intervention. Oncologist 2003, 8:5-17.

3. Leyland-Jones B: Trastuzumab: hopes and realities. Lancet Oncol 2002, 3:137-144.

4. Capdeville R, Buchdunger E, Zimmermann J, Matter A: Glivec (STI571, imatinib), a rationally developed, targeted anticancer drug. Nat Rev Drug Discov 2002, 1:493-502.

5. Hortobagyi GN: Treatment of breast cancer. N Engl J Med 1998, 339:974-984.

6. Chazin VR, Kaleko M, Miller AD, Slamon DJ: Transformation mediated by the human HER-2 gene independent of the epidermal growth factor receptor. Oncogene 1992, 7:1859-1866.

7. Benz CC, Scott GK, Sarup JC, Johnson RM, Tripathy D, Coronado E, Shepard HM, Osborne CK: Estrogen-dependent, tamoxifen-resistant tumorigenic growth of MCF-7 cells transfected with HER2/neu. Breast Cancer Res Treat 1993, 24:85-95.

8. Muss HB, Thor AD, Berry DA, Kute T, Liu ET, Koerner F, Cirrincione CT, Budman DR, Wood WC, Barcos M: c-erbB-2 expression and response to adjuvant therapy in women with node-positive early breast cancer. $N$ Engl J Med 1994, 330: 1260-1266.

9. Yu D, Liu B, Tan M, Li J, Wang SS, Hung MC: Overexpression of c-erbB-2/neu in breast cancer cells confers increased resistance to Taxol via mdr-1-independent mechanisms. Oncogene 1996, 13:1359-1365.

10. Slamon DJ, Leyland-Jones B, Shak S, Fuchs $H$, Paton V, Bajamonde A, Fleming T, Eiermann W, Wolter J, Pegram M, Baselga J, Norton L: Use of chemotherapy plus a monoclonal antibody against HER2 for metastatic breast cancer that overexpresses HER2. N Engl J Med 2001, 344:783-792.

11. Finn OJ: Cancer vaccines: between the idea and the reality. Nat Rev Immunol 2003, 3:630-641.

12. Bodey B, Bodey B, Jr, Siegel SE, Kaiser HE: Failure of cancer vaccines: the significant limitations of this approach to immunotherapy. Anticancer Res 2000, 20:2665-2676.

13. Slingluff $\mathrm{CL}$, Jr, Yamshchikov G, Neese $P$, Galavotti $H$, Eastham $S$, Engelhard VH, Kittlesen D, Deacon D, Hibbitts S, Grosh WW, Petroni G, Cohen R, Wiernasz C, Patterson JW, Conway BP, Ross WG: Phase I trial of a melanoma vaccine with gp100(280-288) peptide and tetanus helper peptide in adjuvant: immunologic and clinical outcomes. Clin Cancer Res 2001, 7:3012-3024.

14. Disis ML, Schiffman K: Cancer vaccines targeting the HER2/neu oncogenic protein. Semin Onco/ 2001, 28:12-20.

15. Fisk B, Blevins TL, Wharton JT, loannides CG: Identification of an immunodominant peptide of HER-2/neu protooncogene recognized by ovarian tumor-specific cytotoxic $\mathrm{T}$ lymphocyte lines. J Exp Med 1995, 181:2109-2117.

16. Disis ML, Grabstein KH, Sleath PR, Cheever MA: Generation of immunity to the HER-2/neu oncogenic protein in patients with breast and ovarian cancer using a peptide-based vaccine. Clin
17. Sondak VK, Liu PY, Tuthill RJ, Kempf RA, Unger JM, Sosman JA, Thompson JA, Weiss GR, Redman BG, Jakowatz JG, Noyes RD, Flaherty LE: Adjuvant immunotherapy of resected, intermediate-thickness, node-negative melanoma with an allogeneic tumor vaccine: overall results of a randomized trial of the Southwest Oncology Group. J Clin Oncol 2002, 20:2058-2066.

18. Antonia SJ, Seigne J, Diaz J, Muro-Cacho C, Extermann M, Farmelo MJ, Friberg M, Alsarraj M, Mahany JJ, Pow-Sang J, Cantor A, Janssen W: Phase I trial of a B7-1 (CD80) gene modified autologous tumor cell vaccine in combination with systemic interleukin-2 in patients with metastatic renal cell carcinoma. $J$ Urol 2002, 167:1995-2000.

19. Dalgleish AG: Cancer vaccines. Br J Cancer 2000, 82:1619-1624.

20. Bargmann $\mathrm{Cl}$, Weinberg RA: Increased tyrosine kinase activity associated with the protein encoded by the activated neu oncogene. Proc Natl Acad Sci USA 1988, 85:5394-5398.

21. Curcio C, Di Carlo E, Clynes R, Smyth MJ, Boggio K, Quaglino E, Spadaro M, Colombo MP, Amici A, Lollini PL, Musiani P, Forni G: Nonredundant roles of antibody, cytokines, and perforin in the eradication of established Her-2/neu carcinomas. J Clin Invest 2003, 111:1161-1170.

22. Overwijk WW, Theoret MR, Finkelstein SE, Surman DR, de Jong LA, Vyth-Dreese FA, Dellemijn TA, Antony PA, Spiess PJ, Palmer DC, Heimann DM, Klebanoff CA, Yu Z, Hwang LN, Feigenbaum L, Kruisbeek AM, Rosenberg SA, Restifo NP: Tumor regression and autoimmunity after reversal of a functionally tolerant state of self-reactive CD8 ${ }^{+} \mathrm{T}$ cells. J Exp Med 2003, 198:569580.

23. Chen $Y$, Hu D, Eling DJ, Robbins J, Kipps TJ: DNA vaccines encoding full-length or truncated $\mathrm{Neu}$ induce protective immunity against Neu-expressing mammary tumors. Cancer Res 1998, 58:1965-1971.

24. Rovero S, Amici A, Carlo ED, Bei R, Nanni P, Quaglino E, Porcedda P, Boggio K, Smorlesi A, Lollini PL, Landuzzi L, Colombo MP, Giovarelli M, Musiani P, Forni G: DNA vaccination against rat her-2/Neu p185 more effectively inhibits carcinogenesis than transplantable carcinomas in transgenic BALB/c mice. J Immunol 2000, 165:5133-5142.

25. Piechocki MP, Pilon SA, Wei WZ: Complementary antitumor immunity induced by plasmid DNA encoding secreted and cytoplasmic human ErbB-2. J Immuno/ 2001, 167:3367-3374.

26. Foy TM, Bannink J, Sutherland RA, McNeill PD, Moulton GG, Smith J, Cheever MA, Grabstein K: Vaccination with Her-2/neu DNA or protein subunits protects against growth of a Her-2/ neu-expressing murine tumor. Vaccine 2001, 19:2598-2606.

27. Amici A, Smorlesi A, Noce G, Santoni G, Cappelletti P, Capparuccia L, Coppari R, Lucciarini R, Petrelli C, Provinciali M: DNA vaccination with full-length or truncated neu induces protective immunity against the development of spontaneous mammary tumors in HER-2/neu transgenic mice. Gene Ther 2000, 7:703-706.

28. Lachman LB, Rao XM, Kremer RH, Ozpolat B, Kiriakova G, Price JE: DNA vaccination against neu reduces breast cancer incidence and metastasis in mice. Cancer Gene Ther 2001, 8:259268.

29. Hengst JC, Mokyr MB, Dray S: Importance of timing in cyclophosphamide therapy of MOPC-315 tumor-bearing mice. Cancer Res 1980, 40:2135-2141.

30. Spreafico F: Heterogeneity of the interaction of anticancer agents with the immune system and its possible relevance in chemoimmunotherapy. Oncology 1980, 37 (Suppl 1):9-18.

31. Gorelik L, Prokhorova A, Mokyr MB: Low-dose melphalaninduced shift in the production of a Th2-type cytokine to a Th1-type cytokine in mice bearing a large MOPC-315 tumor. Cancer Immunol Immunother 1994, 39:117-126.

32. Munkarah A, Chuang L, Lotzova E, Cook K, Morris M, Wharton JT: Comparative studies of taxol and taxotere on tumor growth and lymphocyte functions. Gynecol Oncol 1994, 55:211-216.

33. Hayakawa M, Kawaguchi S, Ishii S, Murakami M, Uede T: B7-1transfected tumor vaccine counteracts chemotherapyinduced immunosuppression and prolongs the survival of rats bearing highly metastatic osteosarcoma cells. Int J Cancer 1997, 71:1091-1102.

34. Komatsumoto M, Hosokawa M, Okada F, Okayasu T, Tanabe T, Kobayashi $\mathrm{H}$ : The improved effects of specific active immunotherapy on a rat fibrosarcoma by antitumor drugs. Cancer Immunol Immunother 1991, 33:279-284. 
35. Relyveld EH, Bizzini B, Ophir R, Ben Efraim S: Synergy between low-dose chemotherapy and immunotherapy in mouse L1210 leukemia. Cancer Treat Rep 1987, 71:241-246.

36. Emens LA, Machiels JP, Reilly RT, Jaffee EM: Chemotherapy: friend or foe to cancer vaccines? Curr Opin Mol Ther 2001, 3: 77-84.

37. Machiels JP, Reilly RT, Emens LA, Ercolini AM, Lei RY, Weintraub D, Okoye Fl, Jaffee EM: Cyclophosphamide, doxorubicin, and paclitaxel enhance the antitumor immune response of granulocyte/macrophage-colony stimulating factor-secreting whole-cell vaccines in HER-2/neu tolerized mice. Cancer Res 2001, 61:3689-3697.

38. Westervelt P, Pollock JL, Oldfather KM, Walter MJ, Ma MK, Williams A, DiPersio JF, Ley TJ: Adaptive immunity cooperates with liposomal all-trans-retinoic acid (ATRA) to facilitate longterm molecular remissions in mice with acute promyelocytic leukemia. Proc Natl Acad Sci USA 2002, 99:9468-9473.

39. Donnelly J: Cancer vaccine targets leukemia. Nat Med 2003, 9: 1354-1356.

40. Padua RA, Larghero J, Robin M, Pogam CC, Schlageter $M H$, Muszlak S, Fric J, West R, Rousselot P, Phan TH, Mudde L, Teisserenc $\mathrm{H}$, Carpentier AF, Kogan S, Degos L, Pla M, Bishop JM, Stevenson F, Charron D, Chomienne C: PML-RARA-targeted DNA vaccine induces protective immunity in a mouse model of leukemia. Nat Med 2003, 9:1413-1417.

41. Dubensky TW, Jr, Driver DA, Polo JM, Belli BA, Latham EM, lbanez CE, Chada S, Brumm D, Banks TA, Mento SJ, Jolly DJ, Chang SM: Sindbis virus DNA-based expression vectors: utility for in vitro and in vivo gene transfer. $J$ Virol 1996, 70: 508-519.

42. Leitner WW, Hwang LN, DeVeer MJ, Zhou A, Silverman RH, Williams BR, Dubensky TW, Ying H, Restifo NP: Alphavirusbased DNA vaccine breaks immunological tolerance by activating innate antiviral pathways. Nat Med 2003, 9:33-39.

43. Pushko P, Parker M, Ludwig GV, Davis NL, Johnston RE, Smith JF: Replicon-helper systems from attenuated Venezuelan equine encephalitis virus: expression of heterologous genes in vitro and immunization against heterologous pathogens in vivo. Virology 1997, 239:389-401.

44. Ikuta Y, Okugawa T, Furugen R, Nagata Y, Takahashi Y, Wang L, Ikeda $\mathrm{H}$, Watanabe M, Imai S, Shiku H: A HER2/NEU-derived peptide, a $\mathrm{K}(\mathrm{d})$-restricted murine tumor rejection antigen, induces HER2-specific HLA-A2402-restricted CD8(+) cytotoxic T lymphocytes. Int J Cancer 2000, 87:553-558.

45. Yee C, Thompson JA, Byrd D, Riddell SR, Roche P, Celis E, Greenberg PD: Adoptive T cell therapy using antigen-specific CD8+ T cell clones for the treatment of patients with metastatic melanoma: in vivo persistence, migration, and antitumor effect of transferred T cells. Proc Natl Acad Sci USA 2002, 99: 16168-16173.

46. Shankaran V, Ikeda H, Bruce AT, White JM, Swanson PE, Old LJ, Schreiber RD: IFNgamma and lymphocytes prevent primary tumour development and shape tumour immunogenicity. Nature 2001, 410:1107-1111.

47. Michel N, Ohlschlager P, Osen W, Freyschmidt EJ, Guthohrlein $\mathrm{H}$, Kaufmann AM, Muller M, Gissmann L: T cell response to human papillomavirus 16 E7 in mice: comparison of Cr release assay, intracellular IFN-gamma production, ELISPOT and tetramer staining. Intervirology 2002, 45:290-299.

48. Snyder JE, Mosmann TR: How to 'spot' a real killer. Trends Immunol 2003, 24:231.

49. Snyder JE, Bowers WJ, Livingstone AM, Lee FE, Federoff HJ, Mosmann TR: Measuring the frequency of mouse and human cytotoxic $T$ cells by the Lysispot assay: independent regulation of cytokine secretion and short-term killing. Nat Med 2003, 9:231-235.

50. Lim DG, Bieganowska BK, Freeman GJ, Hafler DA: Examination of $\mathrm{CDB}^{+} \mathrm{T}$ cell function in humans using MHC class I tetramers: similar cytotoxicity but variable proliferation and cytokine production among different clonal $C D 8^{+} \mathrm{T}$ cells specific to a single viral epitope. J Immuno/ 2000, 165:6214-6220.

51. Slifka MK, Rodriguez F, Whitton JL: Rapid on/off cycling of cytokine production by virus-specific $\mathrm{CD}^{+} \mathrm{T}$ cells. Nature 1999, 401:76-79.

52. Bachmann MF, Barner M, Viola A, Kopf M: Distinct kinetics of cytokine production and cytolysis in effector and memory $T$ cells after viral infection. Eur J Immunol 1999, 29:291-299.
53. Zhang L, Conejo-Garcia JR, Katsaros D, Gimotty PA, Massobrio $M$, Regnani G, Makrigiannakis A, Gray H, Schlienger K, Liebman MN, Rubin SC, Coukos G: Intratumoral T cells, recurrence, and survival in epithelial ovarian cancer. $N$ Engl J Med 2003, 348: 203-213.

54. Haupt K, Roggendorf M, Mann K: The potential of DNA vaccination against tumor-associated antigens for antitumor therapy. Exp Biol Med 2002, 227:227-237.

55. Robinson HL: Prime boost vaccines power up in people. Nat Med 2003, 9:642-643.

56. McConkey SJ, Reece WH, Moorthy VS, Webster D, Dunachie S, Butcher G, Vuola JM, Blanchard TJ, Gothard P, Watkins K, Hannan CM, Everaere S, Brown K, Kester KE, Cummings J, Williams J, Heppner DG, Pathan A, Flanagan K, Arulanantham N, Roberts MT, Roy M, Smith GL, Schneider J, Peto T, Sinden RE, Gilbert SC, Hill AV: Enhanced T-cell immunogenicity of plasmid DNA vaccines boosted by recombinant modified vaccinia virus Ankara in humans. Nat Med 2003, 9:729-735.

57. Srivastava IK, Liu MA: Gene vaccines. Ann Intern Med 2003 , 138:550-559.

58. Hortobagyi GN: Adjuvant therapy for breast cancer. Annu Rev Med 2000, 51:377-392.

59. Pietras RJ, Fendly BM, Chazin VR, Pegram MD, Howell SB, Slamon DJ: Antibody to HER-2/neu receptor blocks DNA repair after cisplatin in human breast and ovarian cancer cells. Oncogene 1994, 9:1829-1838.

60. Pegram MD, Lipton A, Hayes DF, Weber BL, Baselga JM, Tripathy D, Baly D, Baughman SA, Twaddell T, Glaspy JA, Slamon DJ: Phase II study of receptor-enhanced chemosensitivity using recombinant humanized anti-p185HER2/neu monoclonal antibody plus cisplatin in patients with HER2/neu-overexpressing metastatic breast cancer refractory to chemotherapy treatment. J Clin Oncol 1998, 16:2659-2671.

61. Ben Efraim S, Bocian RC, Mokyr MB, Dray S: Increase in the effectiveness of melphalan therapy with progression of MOPC-315 plasmacytoma tumor growth. Cancer Immunol Immunother 1983, 15:101-107.

62. Hilgard P, Pohl J, Stekar J, Voegeli R: Oxazaphosphorines as biological response modifiers-experimental and clinical perspectives. Cancer Treat Rev 1985, 12:155-162.

63. Zagozdzon R, Golab J: Immunomodulation by anticancer chemotherapy: more is not always better. Int J Oncol 2001, 18:417-424.

64. Ehrke MJ, Maccubbin D, Ryoyama K, Cohen SA, Mihich E: Correlation between adriamycin-induced augmentation of interleukin 2 production and of cell-mediated cytotoxicity in mice. Cancer Res 1986, 46:54-60.

65. Maccubbin DL, Wing KR, Mace KF, Ho RL, Ehrke MJ, Mihich E: Adriamycin-induced modulation of host defenses in tumorbearing mice. Cancer Res 1992, 52:3572-3576.

66. Tomazic V, Ehrke MJ, Mihich E: Augmentation of the development of immune responses of mice against allogeneic tumor cells after adriamycin treatment. Cancer Res 1981, 41:33703376.

67. Nigam A, Yacavone RF, Zahurak ML, Johns CM, Pardoll DM, Piantadosi S, Levitsky HI, Nelson WG: Immunomodulatory properties of antineoplastic drugs administered in conjunction with GM-CSF-secreting cancer cell vaccines. Int J Oncol 1998, 12:161-170.

68. Orsini F, Pavelic Z, Mihich E: Increased primary cell-mediated immunity in culture subsequent to adriamycin or daunorubicin treatment of spleen donor mice. Cancer Res 1977, 37: 1719-1726.

\section{Correspondence}

Lawrence B Lachman, Department of Bioimmunotherapy, Unit 362, University of Texas MD Anderson Cancer Center, 1515 Holcombe Boulevard, Houston, TX 77030, USA. Tel: +1 713792 8587; fax: +1 713797 9764; e-mail: Lachman@odin.mdacc.tmc.edu 